\title{
Occult tibial plateau fracture
}

\author{
Naoki Yoshida, Yoshihiko Tsuchida
}

Department of Orthopedic Trauma Surgery,

Shonankamakura General Hospital, Kanagawa, Japan

\section{Correspondence to} Dr Naoki Yoshida, n_yoshida@shonankamakura. or.jp

Accepted 12 September 2017

\section{DESCRIPTION}

An 86-year-old woman presented to the emergency department with diffuse left knee pain from a fall from standing height. Anteroposterior and lateral X-ray of the left knee revealed no evidence of a fracture (figure 1A). However, MRI study revealed left tibial plateau fracture (coronal T2-weighted fast field echo imaging (figure 1B) and coronal proton density-weighted fast spin echo imaging (figure 1C). She was hospitalised for severe left knee pain and was given restrictions on weight-bearing activity for 2 weeks. She achieved good functional outcomes at a 6-month follow-up.

Occult tibial plateau fractures are not be easily diagnosed on a radiograph. For occult tibial plateau fractures, non-operative conservative therapy should be a first-line treatment. ${ }^{1}$ However,

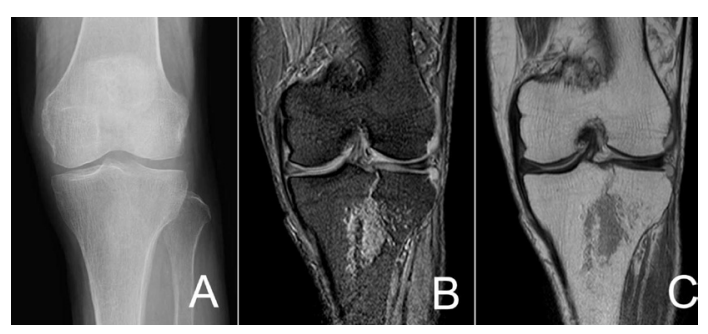

Figure 1 (A) An anteroposterior projection of left knee demonstrated no evidence of fracture. (B) MRI (coronal T2-weighted fast field echo imaging) revealed left tibial plateau fracture. (C) MRI (coronal proton densityweighted fast spin echo imaging) revealed left tibial plateau fracture.

\section{Learning points}

- Occult tibial plateau fractures may not be easily diagnosed on a radiograph.

- MRI studies should be performed in patients with a suspected tibial plateau fracture.

these fractures can cause severe sequelae if they are not properly diagnosed and rapidly treated. ${ }^{2}$ When this occurs, patients may waste time and money compared with appropriate treatment. To prevent potential severe adverse events, MRI studies should be performed in patients with a suspected tibial plateau fracture. ${ }^{3}$

Contributors The patient's care was overseen by both the authors. YT provided assistance with the drafting of the manuscript. Both the authors approved the manuscript prior to submission.

Competing interests None declared.

\section{Patient consent Obtained.}

Provenance and peer review Not commissioned; externally peer reviewed.

(c) BMJ Publishing Group Ltd (unless otherwise stated in the text of the article) 2017. All rights reserved. No commercial use is permitted unless otherwise expressly granted.

\section{REFERENCES}

1 Ye DC, Qiu QD, Yin JC. [MRI diagnosis of bone contusion on the knee and its clinical significance]. Zhongguo Gu Shang 2010;23:427-9.

2 Bellelli A, Nardis P. [Occult or unknown traumatic osteochondral lesions of the knee. Assessment of 19 cases studied with conventional radiology and magnetic resonance]. Radiol Med 1996;91:700-4.

3 Mink JH, Deutsch AL. Occult cartilage and bone injuries of the knee: detection, classification, and assessment with MR imaging. Radiology 1989;170:823-9.
Copyright 2017 BMJ Publishing Group. All rights reserved. For permission to reuse any of this content visit

http://group.bmj.com/group/rights-licensing/permissions.

BMJ Case Report Fellows may re-use this article for personal use and teaching without any further permission.

Become a Fellow of BMJ Case Reports today and you can:

- Submit as many cases as you like

- Enjoy fast sympathetic peer review and rapid publication of accepted articles

- Access all the published articles

- Re-use any of the published material for personal use and teaching without further permission

For information on Institutional Fellowships contact consortiasales@bmjgroup.com

Visit casereports.bmj.com for more articles like this and to become a Fellow 